\title{
Do BRIC Countries' Equity Markets Co-Move in Long Run?
}

\author{
Amanjot Singh ${ }^{*}$, Parneet Kaur ${ }^{2}$ \\ ${ }^{1}$ University School of Applied Management, Punjabi University, Patiala, India \\ ${ }^{2}$ University School of Management Studies, Punjabi University, Patiala, India \\ Email: *amanjot_42@yahoo.com,amanjot288@gmail.com
}

Received 19 January 2016; accepted 28 March 2016; published 31 March 2016

Copyright (C) 2016 by authors and Scientific Research Publishing Inc.

This work is licensed under the Creative Commons Attribution International License (CC BY). http://creativecommons.org/licenses/by/4.0/

(c) (i) Open Access

\section{Abstract}

The present study attempts to empirically analyze the co-movement in the BRIC countries' stock markets in the long run by employing a Johansen cointegration technique. We have divided the sample period into two parts to account for the co-movement during the recent financial crisis. The results indicate no long run co-movement among the BRIC countries as a whole during both of the sample periods. However, the pairwise and multivariate cointegration tests highlight the existence of a co-movement among the Brazilian, Russian and the Chinese markets, excluding Indian during the financial crisis and the period afterwards. Furthermore, the exclusion tests highlight a significant contribution of the Brazilian market in the long run causality in the context of both the Russian and Chinese markets. The Russian market acts as a source of any market shock, further been absorbed by the Brazilian and Chinese markets at the pace of 4 percent per week.

\section{Keywords}

Co-Movement, Cointegration, Financial Crisis, Johansen Approach, Portfolio

\section{Introduction}

The modern portfolio theory has made the investors think about diversification benefits in a portfolio of assets. The diversification would yield more returns only when the correlation among the asset classes in a portfolio is smaller. If an investor invests in a domestic market, then he is exposed to both the domestic fundamentals as well as country specific risks, but if he invests outside the domestic boundaries, then he can certainly enjoy diversification benefits compensating for the risks associated with the domestic market. Nowadays, with the liberalization in terms of trade and financial capital flows, globalization and the emergence of hedge, feeder and

${ }^{*}$ Corresponding author. 
other type of global funds, the investors are having more investment avenues, not only in their domestic economies but also in other economies.

Generally, the fund managers analyze the movement of security prices in their portfolios of an equity class or debt class or a combination of both. But what if, a manager has created a portfolio of indices or Exchange Traded Funds (ETF hereafter) of different countries and makes investments in these indices. Now, apart from analyzing the portfolio returns and risk associated, the manager may firstly try to capture the co-movement among the different markets concerned because a greater degree of co-movement between the countries under investment radars, reduces diversification benefits.

Furthermore, with the opening up of worldwide economies and development of the information and communication technology (ICT), the stock markets have become more efficient in discounting future as well as current information both domestically and internationally. This has led to increasing co-movement and interlinkages among the international stock markets, thereby reducing portfolio diversification benefits. For instance, the data revealed by China about its growing steel demand and on the line expected numbers of the economic indicators cause Indian equity market to witness an upward rally because the Indian steel companies would be in a profitable position with the expectation of increase in exports in near future. This is just a single example highlighting the linkages the countries share with each other due to increasing trade and financial flows.

These equity market linkages could be long term as well as short term. A short term linkage exists only for a few days or months, but a long term linkage or cointegration does not yield benefits for an investor in the long run. So, a proper attention should be given checking the co-movement of the domestic stock markets with the different foreign countries. The existence of any long run co-movement among the markets highlights the presence of a cause and effect relationship among the markets. Over a period of time, numerous researchers have tried to capture the long run co-movement among the developed, frontier and emerging markets. However, the present study attempts to analyze the co-movement in the BRIC countries' stock markets (a case of only emerging markets) in the long run, across the period 2004 to 2013 comprising the global financial crisis period. Apart from this, an attempt has been made to further account for the long run causality relationship between the respective equity markets especially through certain exclusion tests and speed of adjustment parameters.

The term "BRIC" was coined by Jim O’Neill of Goldman Sachs in the year 2001. "BRIC” is a collection of Brazil, Russia, India and China, the most promising emerging market club. The term "BRIC” expanded to "BRICS" in the year 2010, with the inclusion of South Africa in the BRIC basket. The present study has not considered the stock market of South Africa to capture the co-movement because the inclusion of South Africa was done in the year 2010 after the financial crisis of 2007-2009. Secondly, apart from the micro and macroeconomic fundamentals, markets all over the world also get influenced by emotions and herding behavior of the investors. The study assumes that if South Africa would have been the part of the BRIC club well before the crisis; then the response of the BRICS' stock markets collectively would have been different during the crisis period and afterwards.

Over a period of time, China is emerging as a major trading partner among the BRIC nations and the contribution of China ranges from 72\% - 85\%. The trade between Russia and India is slowly increasing. Both India and China contribute approximately 80 percent or more in the imports from and exports to the all other BRICS countries during 1995-2007. Moreover, in terms of Foreign Direct Investments (FDI hereafter) Brazil, China, India and South Africa had been net importers of FDI during the period 1995-2010 whereas Russia was a net exporter in the year 2010, as studied by Mathur and Dasgupta [1]. The increasing trade relations and the financial flows from the one BRIC country to the other have made us to expect a co-movement among the stock markets of the BRIC nations. Besides this, the Morgan Stanley Capital International (MSCI) came out with an MSCI BRIC index in the year 2005, after the Goldman Sachs coined the term "BRIC" nations, keeping in view the economic conditions and similarities shared by the countries. Recently, the BRIC nations have decided to incorporate a new development bank (BRICS Bank) to finance infrastructure, developmental as well as financial safety needs among the basket countries. The creation of an index and the growing financial flows among the BRIC countries has prompted us to explore the long run co-movement among the stock markets of the nations concerned and especially during the episodes of the financial crisis. Reading in these terms, a priori one would expect a long run co-movement among all of the BRIC markets.

The remainder paper is organized as follows: Section 2 highlights the literature review, Sections 3 and 4 spotlight the empirical framework and results, respectively. Section 5 concludes the paper. 


\section{Stock Market Co-Movement and Linkages-A Review}

With the passage of time, different researchers have tried to capture stock market linkages by employing different techniques. When we try to identify a long term or short term relationship among the markets, then the econometric models employed to account for the relationship matters a lot. A few researchers relied on correlation coefficients and others put more stress on time varying robust measures to account for co-movement comprising advanced econometric techniques like VAR/VECM, Granger causality tests and family of GARCH based models. The studies relating to the co-movement among the stock markets also explore the direction of the impact from one market to the other. Some of the studies didn't only focus on the stock market linkages during a tranquil period, but also highlighted the relationship during a crisis period; include the studies like, Forbes and Rigobon [2] and Angkinand et al. [3]. As we earlier discussed that the linkages between the stock markets can be long run as well as short run, but the underlying phenomenon is to check the co-movement among the markets occurring due to the growing integration in the form of trade and financial flows.

Friedman and Shachmurove [4] examined the behavior of the European Community (EC) stock markets in the light of decreased barriers to international investments by employing Vector Autoregression (VAR) model. The authors came out with the results that Britain, France, Germany and the Netherlands are found to be highly related, but the smaller EC markets are more independent. On the other hand, Yang et al. [5] examined the long run price relationship and the dynamic price transmission among the U.S., Germany, and four major Eastern European emerging stock markets, with particular attention to the impact of the 1998 Russian financial crisis. The results reported that both the long run price relationship and the dynamic price transmission got stronger among the markets concerned after the crisis.

To examine the long run equilibrium relationship and short run dynamic linkages between the Indian stock market and the stock markets in the major developed countries (United States, United Kingdom and Japan) after 1990, Wong et al. [6] used the Granger causality relationship and pairwise, multiple and fractional cointegration tests. The results confirmed the integration of Indian stock market with the mature markets. In the short run, both US and Japan Granger causes the Indian stock market, but the same is not true with the Indian market. By moving out of the equity markets, Yang [7] examined the linkages between the government bond markets of five industrialized countries (US, Japan, Germany, UK and Canada) during the period from January 1986 to December 2000 by employing a recursive cointegration technique. The results showed no existence of the long run relationship among the five major bond markets during the sample period.

To understand the extent of co-movement between the liquidity and bank solvency measures in the advanced and emerging market (EM) bond and stock markets, Frank and Hesse [8] employed multivariate GARCH model. The authors came out with the empirical findings that the markets were highly correlated during the crisis period, thereby raising doubts over the theory of decoupling. Instead of focusing only on the advanced economies or the emerging market economies, Chittedi [9] examined the integration of the stock markets among the BRIC (Brazil, Russia, India and China) economies and the developed economies such as the US, UK and Japan across the period 1998 to 2008. The author used different models and tests comprising Granger causality, Johansen cointegration test and Error correction Mechanism (ECM) to confirm the existence of co-movement. The results exhibited that the UK, Brazilian, Russian and Chinese markets do not have a statistically significant impact on the Indian stock market. The study concludes the existence of a cointegration among the markets undertaken for the study. However, the author has considered the sample time period up till 2008, excluding the global financial crisis and the period afterwards thereby creating a research gap.

Maggiora and Skerman [10] investigated cointegrating relationships between four specified European stock markets and the American stock market by using data from the last eight years comprising the "Global Financial Crisis" commencing 2007. The authors highlighted that the S\&P500/FTSE100 (US/UK) are found to be strongly cointegrated across all the sample periods taken for the purpose of study. Similarly, in order to study the comovement and short term and long term relationships among the selected developed stock markets and the emerging stock markets, Modi et al. [11] used the cointegration technique. The results exhibited that the MXX (Mexico), Dowjones (US) and Nasdaq (US) are least dependent on other markets, whereas the Dowjones is the most influential market. Gupta [12] attempted to study the dynamic relations among the emerging countries, especially the BRIC countries during the conditions of financial turmoil i.e. 2008 to 2011. Owing to a shorter time span of about four years, the authors did not come out with a long run co-movement test among the variables undertaken. However, the Granger causality test was applied to the stock indices of the BRIC countries to check 
the direction of movement. India, Russia and China Granger cause Brazil, but the same is not true with Brazil. The Indian economy Granger causes the Russian economy.

Subhani et al. [13] highlighted the co-movement among the stock markets of India, Pakistan, Bangladesh and Nepal by employing Johansen co-integration technique. The authors came out with a finding that there are linkages that exist among the stock prices of Karachi stock exchange with the stock prices of Dhaka stock exchange. To investigate the co-movement of Pakistan's equity market with the markets of India, China, Indonesia, Singapore, Chinese Taipei, Malaysia, Japan, USA and UK, Ali et al. [14] used cointegration tests on monthly stock prices and discovered that there is no co-movement of Pakistan's equity market with the markets of UK, USA, Chinese Taipei, Malaysia and Singapore whereas a co-movement was found between the Pakistan's equity market and India, China, Japan and Indonesia’s equity market.

Jeyanthi [15] examined the long run and short run relationships between the stock prices of the BRIC countries (Brazil, Russia, India and China) across 2000 to 2010. The Engle and Granger cointegration tests revealed no long term integration except with Brazil, which further creates an opportunity for the investors to diversify in the BRIC equity markets with a long term perspective in mind. But in the present study, we are considering a more advanced methodology "Johansen cointegration test" having the capability to identify more than one cointegrating vectors unlike Engle-Granger methodology, coupled with a time period comprising the global financial crisis and the period afterwards. By following a completely new methodology of graphical modelling to account for the integration among the S\&P 500 (US), Nikkei 225 (Japan) and FTSE 100 (UK) markets, Rea et al. [16] concluded that the markets were strongly integrated during the pre-crisis period.

Apart from the above mentioned studies, there are many more studies capturing the co-movement and linkages considering the BRIC economies (for instance, [17]-[21]). Most of these studies have been conducted to explore the contemporaneous or dynamic linkages among the developed and emerging markets, like BRIC markets. But, the literature is quite thin with regards to the long run co-movement among the emerging markets only and that too considering the recent global financial crisis (2007-2009) and the period afterwards. The present study is an attempt to fill this gap and study the linkages and causality that exist between the stock markets of the BRIC countries in the long run with a special emphasis on the financial crisis.

\section{Research Methodology}

To explore the co-movement among the BRIC countries, stock market indices of the respective countries have been undertaken. A broader stock market index reflects a combination of different sectors of an economy. So, the co-movement of different stock markets can be judged from the stock market indices of the respective countries. The stock market indices used for the purpose of the study are CNX NIFTY (for India), BOVESPA (for Brazil), RTS (for Russia) and SSE Shanghai Composite Index (for China).

The weekly data have been collected from ECONSTAT and the website of respective stock exchanges ranging from January 2004 to November 2013 in local currency without converting them into dollar values as this would avoid currency fluctuations. We have used "mean of nearby two points" approach in order to fill out for the non trading weeks. The period undertaken for the study of co-movement comprises the time period relating to the US subprime crisis started way back in 2007 and thereafter converted into full blown global financial crisis. To account for the presence of the crisis, we conducted the research under two different sample periods; full sample period: January 2004 to November 2013 and the crisis period and afterwards: January 2007 to November 2013. At the same time, breakage of financial time series data and application of lesser frequency weekly data would keep into check structural breaks in the data. The logged values of stock indices are factored into the cointegration model because the logged values help in reducing heteroskedasticity present in the data. The analysis has been done with the help of MS Excel, SPSS software and EVIEWS software.

\subsection{Unit Root Test}

The financial time series suffers from the problem of non-stationarity. The term stationary means that the series should be mean reverting and standard deviation should be time invariant. In order to check the stationarity, the Augmented Dickey Fuller test has been used. The Augmented Dickey Fuller test augments the lagged values of the dependent variable in the series:

$$
\Delta Y t=\beta_{1}+\beta_{2} t+\delta Y_{t-1}+\sum_{i=1}^{p} \alpha_{i} \Delta Y_{t-i}+\varepsilon_{t}
$$


where $\beta_{1}$ is a drift parameter, $\beta_{2}$ is the coefficient on time component $(t), \delta$ is the testing coefficient of unit root, $p$ is the lag order of first difference series, $\alpha_{i}$ is the coefficient of lagged first difference series and $\varepsilon_{t}$ is a pure white noise error term. The null hypothesis is $\delta=0$, where $\delta=(p-1)$ and the alternate hypothesis is $\delta<0($ or $p<1)$. The acceptance of the null hypothesis proclaims the existence of a unit root in a series, making it non stationary, whereas the alternate hypothesis states that the series is a stationary one.

\subsection{Cointegration Analysis}

It is always advisable to check for the presence of a unit root in the series otherwise it would lead to a spurious regression. But sometimes, although the variables are non stationary yet the residuals derived from the regression equation happens to be stationary. The stationary residuals highlight the existence of a long run association and co-movement between the variables undertaken, which can further be stated as cointegration between the variables. In simple terms, variables are termed to be cointegrated when a linear combination of them, integrated of order one $\mathrm{I}(1)$, is found to be stationary. To examine the existence of cointegration, the time series data should be integrated of the same order I(1). In other words, the series should be non-stationary at level, but should become stationary at first difference.

If a long run association has been observed between the variables, then we can further analyze any disequilibrium if arises. The cointegration will make the variables to move in equilibrium, but if any disequilibrium arises then that will be corrected through short run adjustments and the equilibrium position will be restored. The global investors will stand to gain only if the co-movement among the countries is at a minimal level. The present study employs Johansen cointegration approach to account for co-movement in the variables. We have also tried to ascertain pairwise cointegration among the different variables (countries) apart from multivariate cointegration through the Johansen approach.

\subsection{Johansen’s Maximum Likelihood Method}

The Johansen method is a maximum likelihood approach based on two likelihood tests; Trace test and Max Eigenvalue test, proposed by Johansen [22] [23]. The method finds out the cointegrating vectors, which are further introduced in the Vector Autoregression model (VAR hereafter) by imposing certain restrictions known as Vector Error Correction Model (VECM hereafter). The VECM model analyzes the short run as well as long run equilibrium relationship among the variables. The existence of a cointegrating vector exhibits the presence of a long run equilibrium relationship among the variables. The Johansen method is defined as:

$$
\Delta x_{t}=\sum_{i=1}^{p-1} \pi_{i} \Delta x_{t-i}+\alpha \beta^{\prime} u_{t-1}+\varepsilon_{t}
$$

where $x_{t}$ is a non stationary series (stock index), $\pi_{i}$ is a matrix of coefficients, $\alpha$ is speed of adjustment parameter, $p$ is lag order of the first differenced series, $\beta^{\prime}$ is cointegrating vector, $u$ is the error correction term and $\varepsilon_{t}$ is the residual term, as in Enders [24]. The Johansen approach provides two alternate test statistics to examine cointegration: the Trace Test and the Maximum Eigenvalue Test. Under the Trace test, the null hypothesis is there is no cointegrating vector $\left(h_{0}: r=0\right)$ whereas the alternative hypothesis of cointegration is $n$ cointegrating vectors $\left(h_{1}: r>0\right)$. The Maximum Eigenvalue test tests the null hypothesis that the number of cointegrating vectors is equal to $r$ whereas the alternative hypothesis tests the number of cointegrating vectors as $r+1$.

$$
\begin{gathered}
\lambda_{\text {trace }}(r)=-T \sum_{i=r+1}^{n} \ln \left(1-\lambda_{i}^{\wedge}\right) \\
\lambda_{\max }(r, r+1)=-T \ln \left(1-\lambda_{r+1}^{\wedge}\right)
\end{gathered}
$$

where $r=$ number of cointegrating vectors, $\lambda_{i}^{\wedge}$ is the estimated eigenvalue from the $\alpha \beta^{\prime}$ matrices and $T$ is the number of usable observations. The Johansen test of cointegration requires that the lag lengths should be appropriate and the present study employs Akaike's Information Criteria (AIC) to ascertain the lag lengths. To check the lag lengths, we have firstly employed a VAR model at level, wherein the stock market indices among which we try to capture co-movement are taken as endogenous variables. The finding of a stochastic trend among the variables concerned further entail to the adoption of Vector Error correction model (VECM) wherein the first 
differences of the variables are regressed against their lags and a error correction term to account for a disequilibrium in the relationship. Eventually, to restore the equilibrium level among the variables, the coefficient of the error correction term is required to be negative and statistically significant.

The unit root test, lag lengths and cointegration analysis have been performed separately for two sample periods undertaken for the purpose of study. The observed cointegrating vectors among the BRIC countries are further normalized taking each country as a separate dependent variable. Moreover, for detailed justifications, all the variables shall be taken as part of exclusion tests. The exclusion test would spotlight that whether the respective variables are contributing to the long run causation or not through asymptotic chi-square restriction model.

\section{Analysis and Empirical Findings}

Figure 1 reports a graphical presentation of the stock market indices of the respective BRIC countries. The graphical presentation shows that the indices share somewhat co-movement with each other. The global financial crisis and especially the period after September 2008 have made the indices to move in a somewhat similar pattern. The markets in all of the BRIC countries were at zenith during the year 2007 but a downward trend initiated in the year 2008 when the US subprime crisis spillover to the other parts of the world and the emerging markets were not an exception to that. After having a look at the graph, we have calculated Pearson correlation coefficients to ascertain the co-movement among the markets in the full sample period. Table 1 shows the correlation coefficients along with their significant values. The correlation test has been performed on raw series without converting them into log values.

All the coefficients are found to be significant. The correlation among Brazil and India is the highest $(0.923)$ and positive. A change in one variable entails to a positive change in another variable. India and China have the lowest level of correlation (0.588) with each other, whereas the correlation coefficient between China and Russia is 0.708 which is again very high. The results of correlation coefficients highlight a very strong co-movement between Brazilian stock market and Indian stock market. The correlation coefficient between Brazil and Russia is 0.752. Although correlation is a good measure to account for co-movement among the variables concerned, yet it is not a robust measure. What is the strength of relationship between the variables is not a task performed by the correlation coefficients. But still they help in creating an overall impression about the movement and the co-movement of the stock markets.

Furthermore, we checked the logged values of the stock indices for ensuring stationarity both at the level and at first difference. For the full sample period, all of the indices are found to be non stationary at level, whereas the indices are found to be stationary after taking the first difference (5\% significance level). All the series are integrated of the same order I(1). This is the first and foremost condition of Johansen test that the series should be non stationary at level but stationary after taking first difference. In order to check the presence of cointegrating vectors, the non stationary logged series are used and factored into Johansen methodology.

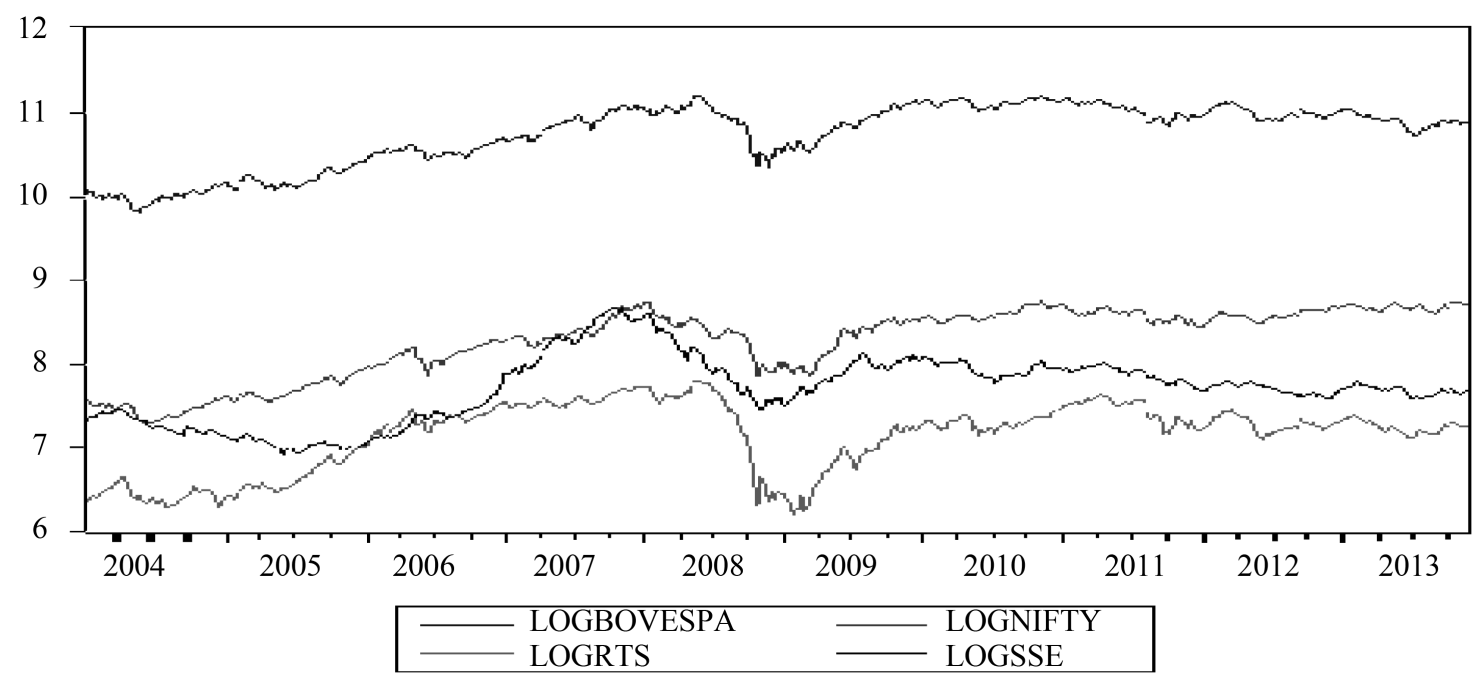

Figure 1. Graphical presentation of stock indices of BRIC countries. Source: Authors' calculation. 
Table 1. Pearson correlation coefficients among the stock indices.

\begin{tabular}{|c|c|c|c|c|c|}
\hline & & RTS & SSE & Nifty & Bovespa \\
\hline \multirow[t]{2}{*}{ RTS } & Correlation & 1 & & & \\
\hline & Sig. (2-tailed) & & & & \\
\hline \multirow[t]{2}{*}{ SSE } & Correlation & $0.708^{* *}$ & 1 & & \\
\hline & Sig. (2-tailed) & $(0.000)$ & & & \\
\hline \multirow[t]{2}{*}{ Nifty } & Correlation & $0.721^{* *}$ & $0.588^{* *}$ & 1 & \\
\hline & Sig. (2-tailed) & $(0.000)$ & $(0.000)$ & & \\
\hline \multirow[t]{2}{*}{ Bovespa } & Correlation & $0.752^{* *}$ & $0.675^{* *}$ & $0.923^{* *}$ & 1 \\
\hline & Sig. (2-tailed) & $(0.000)$ & $(0.000)$ & $(0.000)$ & \\
\hline
\end{tabular}

${ }^{* *}$ Correlation coefficients are significant at the 1 percent significance level. Source: Authors’ calculation.

\subsection{Long Run Co-Movement among the BRIC Countries (Jan 2004 to Nov 2013)}

Table 2 shows the results of the Johansen test for the BRIC countries as a whole during 2004 to 2013. We failed to reject the null hypothesis of the Trace test as well as Max test even at $10 \%$ significance level.

The acceptance of the null hypothesis of no cointegration among the variables depicts that there is no long term co-movement among the BRIC countries as a whole during the period 2004 to 2013. The non existence of cointegrating vectors among the BRIC countries spotlights the fact that the BRIC countries as a whole do not have a long run relationship with each other but there can certainly be short run linkages among the markets. We have not touched the topic of short run linkages among the BRIC countries. But in the long run, the BRIC countries do provide diversification benefits.

\subsection{Pair Wise Cointegration Analysis (Jan 2004 to Nov 2013)}

We have also tried to examine the pairwise cointegration among the countries. Even the results of the pairwise cointegration test failed to reject the null hypothesis of no cointegration among the countries. The results are insignificant even at the $10 \%$ significance level. Six pairs of the countries have been created to analyze the long run co-movement; Brazil-Russia, Brazil-India, Brazil-China, Russia-India, Russia-China and lastly India-China. The period during 2004 to 2013 is fairly a very long period of time and no long run relationship among the BRIC countries is truly a beneficial thing for global investors. The results reported by the cointegration analysis bring into being a new fact that even though the BRIC nations are increasing their integration with each other through various bilateral trade agreements and opening up their financial sector yet the stock markets are not cointegrated in the long run, making them independent. A portfolio of BRIC countries' equity indices can be created to enjoy the diversification as well as international exposure benefits.

\subsection{Long Run Co-Movement among the BRIC Countries (Jan 2007 to Nov 2013)}

The period which we have covered, from the year 2004 to 2013 comprises the period of global financial crisis as well. So, in order to have a more detailed look at the co-movement among the markets, we have taken into consideration the crisis period as well as the period after the crisis. The Johansen test has been applied on the stock market indices of the BRIC countries during the period starting 2007 up till 2013.

Instead of working directly on the indices and cointegration, we again examined the stationary of the data during the period 2007 to 2013. The logged series are found to be non stationary at level, but stationary after taking the first difference. In other words, the series are integrated of the same order I(1). Table 3 shows the results of the Johansen test of cointegration. Even during this period, we failed to reject the null hypothesis of the Trace test as well as the Max test, thereby leading to no cointegrating relationship among the BRIC countries as a whole during the period from 2007 to 2013. There is no long run relationship among the BRIC countries’ equity markets.

The results are not significant even after taking 10\% significance level. The results of the Johansen test for both the sample periods show no sign of cointegration among the countries. The results are somewhat compatible with the findings of Jeyanthi [15] who came out with the results that there is no long run association between 
Table 2. Johansen results for BRIC as a whole.

\begin{tabular}{ccccc}
\hline Null hypothesis & Alternate hypothesis & $\begin{array}{c}\mathbf{9 5 \%} \\
\text { critical value }\end{array}$ & $\begin{array}{c}\mathbf{9 0 \%} \\
\text { critical value }\end{array}$ \\
\hline Trace test & & Trace value & 44.50 \\
$r=0$ & $r>0$ & 24.25 & 47.85 & 25.12 \\
Max test & & Max value & 27.58 & 12.67 \\
$r=0$ & $r=1$ & & & \\
\hline
\end{tabular}

Source: Authors’ calculation.

Table 3. Johansen results for BRIC as a whole.

\begin{tabular}{|c|c|c|c|c|}
\hline Null hypothesis & Alternate hypothesis & & $\begin{array}{c}95 \% \\
\text { critical value }\end{array}$ & $\begin{array}{c}90 \% \\
\text { critical value }\end{array}$ \\
\hline \multicolumn{5}{|c|}{ Trace value } \\
\hline$r=0$ & $r>0$ & 40.57 & 47.86 & 44.50 \\
\hline Max test & & Max value & & \\
\hline$r=0$ & $r=1$ & 22.70 & 27.58 & 25.12 \\
\hline
\end{tabular}

Source: Authors’ calculation.

the BRIC countries except with Brazil by employing Engle-Granger test of cointegration.

\subsection{Pair Wise Cointegration Analysis (Jan 2007 to Nov 2013)}

We have also performed pairwise cointegration tests among the countries for the period 2007 to 2013. Interesingly, we found a cointegrating relationship between Brazil-Russia and Brazil-China. Both the Trace test and Max test revealed two cointegrating vectors (significant at the 5\% level) among the Brazil and Russia, whereas only Trace test found out two cointegrating vectors among Brazil and China (significant at the 5\% level). Taking cue of the presence of cointegrating relationship pairwise, we further tried to examine the cointegration in a multivariate framework among the Brazilian, Russian and Chinese markets, excluding Indian.

\subsection{Long Run Co-Movement among Brazil Russia and China (Jan 2007 to Nov 2013)}

Table 4 indicates the presence of one cointegrating vector among the countries. There is a long run co-movement among Brazil, Russia and China during the financial crisis and the period after the crisis. The global financial crisis had an impact not only on the trade linkages, but on the financial linkages as well that are shared by the countries. Frank and Hesse [8] spotlighted the movement of funds from the emerging markets to the safest havens during the crisis period thereby spreading the crisis to the emerging markets as well. The flow back of funds from the emerging markets made the latter to witness a downward rally in their respective stock markets. The observed cointegrating vector or the long run co-movement is due to the financial crisis going on during that period. The trace test as well as Max test rejects the null hypothesis of no cointegration among the countries.

The presence of one cointegrating vector indicates long run relationship among the countries concerned during the crisis period. The co-movement reduces diversification benefits for the investors. The Johansen test results highlight a very significant fact that the Indian equity market is an independent market post the financial crisis because when we tested cointegration among the BRIC countries as a whole, then we did not find out any long run relationship. However, when we excluded India from the group, we witnessed a long run relationship between the rest of the countries. So, an investor can certainly enjoy benefits by making investments in the Indian equity market in the long run. The results relating to the independence of the Indian stock markets post the global financial crisis are compatible with the findings of Saji [25]. The author came out with the findings that the Indian stock market is loosely linked with the other markets post the global financial crisis validating the case for the investors, especially the international investors to diversify their holdings in India. Now, we move on to certain exclusion tests and other long run causation related tests among Brazil, Russia and China. 
Table 4. Johansen results for Brazil Russia and China.

\begin{tabular}{|c|c|c|c|c|}
\hline Null hypothesis & Alternate hypothesis & & $\begin{array}{c}95 \% \\
\text { critical value }\end{array}$ & $\begin{array}{c}90 \% \\
\text { critical value }\end{array}$ \\
\hline \multicolumn{5}{|c|}{ Trace value } \\
\hline$r=0$ & $r>0$ & $35.38^{*}$ & 29.80 & 27.06 \\
\hline $\mathrm{r} \leq 1$ & $\mathrm{r}>1$ & 13.14 & 15.49 & 13.42 \\
\hline Max test & & Max value & & \\
\hline$r=0$ & $r=1$ & $22.24^{*}$ & 21.13 & 18.90 \\
\hline $\mathrm{r}=1$ & $\mathrm{r}=2$ & 10.91 & 14.26 & 12.30 \\
\hline
\end{tabular}

Source: Authors' calculation. ${ }^{*}$ Indicates the existence of one cointegrating vector.

Firstly, the normalized cointegrating coefficients are computed by taking Brazil as the dependent variable. The results (Table 5) show that the Russian market has a positive long run impact on the Brazilian market, whereas the Chinese market has a negative long run impact on the Brazilian market. When we convert the normalized coefficients in a regression equation form, then the signs also get changed. A one point change in the Russian stock market entails to 0.21 point increase in the Brazilian market. Similarly, a one point change in the Chinese stock market leads to a decrease in the Brazilian market by 0.02 points. These changes have an impact on the long run equilibrium among the markets. On a similar note, when we took the Russian market as the dependent variable, then we came out with a finding that the Brazilian (4.767) and Chinese markets (0.082) have an increasing impact on the Russian market. On the other hand, the Brazilian and Russian markets have a negative (-57.945) and positive (12.154) impact on the Chinese market respectively in the long run.

When we normalize the cointegrating equation by taking Russia as the dependent variable, then the exclusion tests came out with the finding that the Brazilian and Chinese markets jointly have an impact on the Russian market (15.2358, p < 0.05). Furthermore, the exclusion test supports the rejection of the null hypothesis: Brazilian market does not contribute to the long run relationship with the Russian market $(10.6974, \mathrm{p}<0.05)$. Similarly, when we normalize the equation by taking the Chinese market as dependent variable, then the exclusion tests came out with the finding that both the Brazilian and Russian markets jointly contribute to the long run relationship (18.2887, $\mathrm{p}<0.05$ ). On a similar note, the impact of Brazilian market is also found to be in existence individually. It means that the Brazilian market cannot be excluded from the cointegration equation in the context of both the Chinese and Russian markets. But when we took the Brazilian market as the dependent variable for normalization, then both the Russian and Chinese markets failed to reject the null hypothesis of no significant contribution to the long run equilibrium relationship and therefore can be excluded from the cointegrating equation.

To further understand the relationship between the markets and equilibrium restoration, we employed Vector Error Correction Model (VECM) taking the Brazilian market as the dependent variable. Table 6 shows the coefficients of respective error correction terms or speed of adjustment parameters to restore long run relationship. The Johansen test of cointegration discovers the existence of a cointegrating vector, i.e. existence of long run equilibrium relationship among the variables. However, it may be possible that there is disequilibrium in the short run. So, the VECM model helps in analysing the speed of adjustment whenever a disequilibrium situation arises with the help of coefficient of error correction term. Only the Brazilian and Chinese markets' coefficients are found to be statistically significant with the negative values. A positive shock in the markets would get restored to the equilibrium level due to the negative values of the error correction terms. Only $4 \%$ adjustments take place in the first week and the rest take place in the coming weeks in case of both the Brazilian and Chinese markets. The coefficient of the Russian market is not found to be statistically different from zero as per t-statistics, which brings to light that the Russian market is weakly exogenous. So, the Russian market is the first market which gets affected by the errors or shocks and then it transmit the shocks to the other markets of Brazil and China. A reason that could be attributed to this could be that Russia is an energy rich country and the biggest exporter of these resources. Any shock in these resources makes the other countries like Brazil and China, which are energy consumers to feel the brunt and witness the spillover of the events taking place in the Russian economy. Similarly, when we took the Russian market and Chinese market as the dependent variables then 
Table 5. Normalized cointegrating coefficients (standard error in parentheses).

\begin{tabular}{ccc}
\hline LOGBOVESPA & LOGRTS & LOGSSE \\
\hline 1.00000 & -0.209757 & 0.017258 \\
& $(0.10407)$ & $(0.12664)$ \\
\hline
\end{tabular}

Source: Authors’ calculation.

Table 6. Coefficients of error correction terms.

\begin{tabular}{cccc}
\hline & D (LOGBOVESPA) & D (LOGRTS) & D (LOGSSE) \\
\hline Error Correction Term & -0.038458 & 0.021312 & -0.037721 \\
& $(0.01571)$ & $(0.02244)$ & $(0.01487)$ \\
\hline
\end{tabular}

Standard errors in () \& t-statistics in []. Source: Authors’ calculation.

similar type of results comes into observation, wherein the Brazilian and Chinese markets are playing an important role in restoring the equilibrium. Lastly, it is pertinent to mention that the derived standardized residuals are found to be independent justifying the adequacy of the model thereon.

\section{Concluding Remarks}

The co-movement of the equity markets especially in the long run is detrimental to the interest of investors. The increasing correlation has an impact on the portfolio risks and returns. We divided our study in two sample periods in order to include the time period relating to the global financial crisis. The results are somewhat in line with the other researchers. During the full sample period, there is no long run relationship between the markets. Even the pairwise cointegration test does not reveal any cointegrating vector among the pairs. It gives an opportunity to the investors to invest in the BRIC countries with a long run perspective and enjoy the diversification benefits. The fund managers can even create a portfolio of only BRIC countries or a combination of BRIC and other emerging markets which do not share a co-movement with each other. So, the empirical results critically support the construction of a portfolio comprising stocks from the respective BRIC equity markets owing to the non-existence of a long run co-movement with each other. Furthermore, the stocks from the BRIC equity markets act as a strong candidate for reducing portfolio risk without sacrificing the adjusted portfolio returns.

The results reported by the cointegration analysis during the period of financial crisis and afterwards are different from the full sample period results. The markets get highly integrated perhaps co-move with each other during a crisis like event due to spillover mechanisms. We have observed similar kind of trends during this period. The pairwise cointegration analysis reveals the existence of cointegrating vectors among Brazil-Russia and Brazil-China during the financial crisis and the period afterwards. We further extend our study by employing Johansen cointegration test on the Brazilian, Russian and Chinese markets only and leaving the Indian market. One cointegrating vector has been observed among the countries. The exclusion tests also came out with a finding that the Brazilian market cannot be excluded from the cointegration equation in the context of both the Chinese and Russian markets. Whenever a disequilibrium arises then only $4 \%$ adjustments take place in the Brazilian and Chinese markets in the first week and the rest takes place in the coming weeks. Reading in these terms, the Russian market is the first market which gets affected by the errors or shocks and then it transmits the shocks to the other markets of Brazil and China.

Overall, we can say that during a tranquil period, the BRIC markets do not cointegrate with each other, but during a crisis period, a co-movement emerges out among the countries except the Indian markets. Indian equity market is becoming an investment avenue for the international investors owing to its domestic favourable fundamentals and structural economic reforms undertaken post the crisis period. Notwithstanding, Brazilian, Russian and Chinese equity markets share a long run stochastic trend after the US financial crisis got unleashed; yet the respective markets are substantially independent considering the overall sample period. So, the domestic as well as international fund managers should discount this long run relationship shared between the respective BRIC equity markets well ahead of time to maintain their portfolio values. The present study is limited only to- 
wards long run relationship among the variables. The relationship can further be extended to include short run linkages among the markets over a period of time.

\section{References}

[1] Mathur, S. and Dasgupta, M. (2013) BRICS: Trade Policies, Institutions and Areas of Deepening Cooperation. Swati Communications, New Delhi.

[2] Forbes, K.J. and Rigobon, R. (2002) No Contagion, Only Interdependence: Measuring Stock Market Comovements. The Journal of Finance, 57, 2223-2261. http://dx.doi.org/10.1111/0022-1082.00494

[3] Angkinand, A.P., Barth, J.R. and Kim, H. (2009) Spillover Effects from the U.S. Financial Crisis: Some Time-Series Evidence from National Stock Returns. In: Gup, B., Ed., The Financial and Economic Crises: An International Perspective, Edward Elgar Publishing, Cheltenham.

[4] Friedman, J. and Shachmurove, Y. (1997) Using Vector Autoregression Models to Analyze the Behavior of the European Community Stock Markets. CARESS Working Paper 97-04. http://economics.sas.upenn.edu/system/files/97-04.pdf

[5] Yang, J., Hsiao, C., Li, Q. and Wang, Z. (2005) The Emerging Market Crisis and Stock Market Linkages: Further Evidence. IEPR Working Paper, University of Southern California, Los Angeles.

[6] Wong, W.K., Agarwal, A. and Du, J. (2005) Financial Integration for India Stock Market: A Fractional Cointegration Approach. Department of Economics, National University of Singapore, Singapore.

[7] Yang, J. (2005) International Bond Market Linkages: A Structural VAR Analysis. International Financial Markets, Institutions and Money, 15, 39-54. http://dx.doi.org/10.1016/j.intfin.2004.02.001

[8] Frank, N. and Hesse, H. (2009) Financial Spillovers to Emerging Markets during the Global Financial Crisis. Czech Journal of Economics and Finance, 59, 507-521.

[9] Chittedi, K.R. (2009) Global Stock Markets Development and Integration: With Special Reference to BRIC Countries. Paper presented at Issues in Finance and Economic Development in Developing Countries, Shri Ram College of Commerce, University of Delhi. http://mpra.ub.uni-muenchen.de/18602/

[10] Maggiora, D.D. and Skerman, R. (2009) Johansen Cointegration Analysis of American and European Stock Market Indices: An Empirical Study. School of Economics and Management, Lund University, Lund.

[11] Modi, A.G., Patel, B.K. and Patel, N.R. (2010) The Study on Co-Movement of Selected Stock Markets. International Research Journal of Finance and Economics, 47, 171-185.

[12] Gupta, S. (2011) Study of BRIC Countries in the Financial Turmoil. International Affairs and Global Strategy, 1, 1-15.

[13] Subhani, M.I., Hasan, S.A., Mehar, A. and Osman, A. (2011) Are the Major South Asian Equity Markets Co-Integrated? International Journal of Humanities and Social Science, 1, 117-121.

[14] Ali, S., Butt, B.Z. and Rehman, K. (2011) Comovement between Emerging and Developed Stock Markets: An Investigation through Cointegration Analysis. World Applied Sciences Journal, 12, 395-343.

[15] Jeyanthi, B.J. (2012) Are the BRIC Equity Markets More Interdependent after the Global Financial Crisis? http://www.indiastat.com/article/43/jeyanthi/fulltext.pdf

[16] Rea, A., Rea, W., Reale, M. and Scarrott, C. (2012) A Comparison of Spillover Effects before, during and after the 2008 Financial Crisis. Working Paper, Department of Economics and Finance, University of Canterbury, Canterbury.

[17] Shachmurove, Y. (2006) Dynamic Linkages among the Stock Exchanges of the Emerging Tigers of the Twenty First Century. International Journal of Business, 11, 319-344.

[18] Bhar, R. and Nikolova, B. (2009) Return, Volatility Spillovers and Dynamic Correlation in the BRIC Equity Markets. An Analysis Using a Bivariate EGARCH Framework. Global Finance Journal, 19, 203-218. ttp://dx.doi.org/10.1016/j.gfj.2008.09.005

[19] An, L. and Brown, D. (2010) Equity Market Integration between the US and BRIC Countries: Evidence from Unit Root and Cointegration Test. Research Journal of International Studies, 16, $15-24$.

[20] Sheu, H.-J. and Liao, C.-H. (2011) Dynamics of Stock Market Integration between the US and the BRIC. African Journal of Business Management, 5, 3674-3689.

[21] Zhong, M., Chang, T. and Tzeng, H.-W. (2014) International Equity Diversification between the United States and BRICS Countries. Romanian Journal of Economic Forecasting, XVII, 123-138.

[22] Johansen, S. (1991) Estimation and Hypothesis Testing of Cointegration Vectors in Gaussian Vector Autoregressive Models. Econometrica, 59, 1551-1580. http://dx.doi.org/10.2307/2938278

[23] Johansen, S. (1995) Likelihood-Based Inference in Cointegrated Vector Autoregressive Models. Oxford University 
Press, Oxford. http://dx.doi.org/10.1093/0198774508.001.0001

[24] Enders, W. (2014) Applied Econometric Time Series. John Wiley \& Sons, Inc., Hoboken.

[25] Saji, T.G. (2014) Has the Global Financial Crisis Made India’s Stock Market More Independent? IUP Journal of Applied Finance, 20, 83-93. 